Early in 1943 the Iowa General Assembly conferred added wartime powers upon the Hawkeye executive somewhat broad in character. Already in New York through its new War Council, of which Gov. Thos. E. Dewey is chairman, the state announces its responsibility for the enforcement of price ceilings through the state courts and other means at its command. This action is based upon the assumption that Federal control of prices has bogged down and is proving ineffective.

Unmistakably there is gathering a storm of protest and resistance against the encroachment of Federal entering of the realm of activities considered as reserved to the states. The pressing of the "poll tax" abolishment bill in congress, aside from actual merits of the proposed legislation, brings forward the issue of where Federal authority should end and that of the states begin. While the initial conference of midwestern governors avoided public discussion or pronouncement upon other than the immediate problems of their section, those participating were surcharged with the same resentment that occasioned expression by others over the ignoring of state governments by the Federal bureaus and other agencies. Out of this situation appears an almost spontaneous upheaval in the state governments in a wide-spread demand that congress recognize the rightful limitations of Federal activities, as again evidenced at the meeting of governors at Columbus, Ohio.

\title{
OVER A CENTURY OF IOWA WEATHER
}

United States army officers at frontier posts in the Hawkeye state were making scientific recordings of Iowa weather for the weather bureau as early as 1824, according to Dr. John H. Haefner of the State University at Iowa City, disclosing that Iowa weather has been made "of record" for nearly 120 years.

The first fully equipped weather bureau station in the state was set up at Davenport in 1872; followed by others at Keokuk and Dubuque in 1873; Des Moines in 1887, and Sioux City in 1889.-Nevada Evening Journal. 
Copyright of Annals of Iowa is the property of State of Iowa, by \& through the State Historical Society of Iowa and its content may not be copied or emailed to multiple sites or posted to a listserv without the copyright holder's express written permission. However, users may print, download, or email articles for individual use. 